Hoog van de Toren

\title{
Mila Tukker
}

\section{Dictatuur van het pluretariaat}

\author{
Hoe historici zich wegwijs kunnen maken in een multi- \\ interpretabele wereld
}

\begin{abstract}
Wetenschap gaat steeds meer over taligheid en woordgebruik. De democratisering van kennis heeft iedereen in staat gesteld om te onderzoeken. Velen van hen zijn echter niet wegwijs of capabel en zullen deze democratisering gebruiken als een recht om haastige aannames en subjectiviteit te af te dwingen. Onderzoekers dienen een rots te vormen tegen onzorgvuldige interpretaties door transparant te zijn en oog te hebben voor het gewicht van hun woorden. Juist door de grenzen van het menselijk onderzoek aan te geven, kunnen historici aan het publiek garanderen dat hun bevindingen rusten op een gegrond en zorgvuldig proces.
\end{abstract}

In de geschiedschrijving is taal een belangrijk instrument. De woordkeuze van aangeschreven historici is secuur en omvattend, doch subtiel. Met de intrede van de postmodernistische epistemologie hebben geesteswetenschappers meer te kampen met het gewicht en de implicaties van hun woorden. Door ons te wijzen op een fundamentele standplaatsgebondenheid heeft de stroming ons de kracht van taal laten zien en hoe deze doorwerkt in de herinnering van anderen.

Taal is niet alleen cruciaal bij het schetsen van een compleet verhaal, het brengt ook karakter en eigenzinnigheid in onderzoeken. Ik denk dat de academische historicus in een tijd van gepolitiseerde journalistiek en doorgeschoten ideologische argwaan, het postmodernisme kan gebruiken als gereedschap om de pluralistische aard van de herinnering geloofwaardig te maken. In dit betoog beargumenteer ik dat historici zich kunnen 
verdedigen tegen beschuldigingen van vooringenomenheid door meer te letten op hun woordgebruik en wetenschappelijke transparantie. Met wetenschappelijke transparantie hanteer ik een definitie die slaat op het gebruiken van verantwoorde bronnen en onderzoekdoelstellingen. Anno 2019 wordt de autoriteit van een onderzoeker veel meer in twijfel getrokken dan voorheen. Deze ontwikkeling wordt veroorzaakt door de culturele omslag van de postmodernistische stroming en de democratisering van het onderzoek.

Gedurende de jaren zestig hebben historici zoals Michel Foucault sterke argumenten geleverd tegen de normatieve betekenis van het geschreven woord. Foucault stelde dat taal een impliciete betekenis heeft en dat deze betekenis kan worden afgeleid van de heersende ideologie. ${ }^{1}$ Deze ideologie zou middels taal bepaalde begrippen als 'normaal' of 'gangbaar' zien en hiermee uitingen van macht of ethisch gespannen kwesties relativeren. ${ }^{2}$ Veel kritiek kwam er bijvoorbeeld op de definiëring 'Verlichting' omdat deze benaming de West-Europese ontwikkeling en cultuur als uitgangspunt zou nemen. Voorafgaand aan de jaren zestig was de aanname dat de ideeën stammende uit de Verlichting universeel waren. Foucault toonde aan dat juist deze aanspraak op universaliteit een deel was van de inherente ideologische waarden binnen het westerse liberalisme. ${ }^{3}$ Taal werd in deze zin gebruikt als machtsmiddel. Alles dat afweek van een bepaalde norm werd afgedaan als een bedreiging voor het functioneren van de maatschappij.

Deze uiterst kritische observatie werkte door in het academische debat. Wetenschappers gingen zich afvragen of het nog wel mogelijk was om de realiteit te analyseren als woorden geen heldere uitlegkracht meer hadden. De Franse filosoof Jean-Jacques Lyotard beaamde dat met de komst van het postmodernisme, de wetenschap zich officieel op een nieuw speelveld bevond. Het postmodernisme indiceerde volgens hem een postindustriële tijd waarin taal en semantiek de toon van het debat zijn gaan voeren omdat technische innovatie teleologische theorieën overbodig had gemaakt. ${ }^{4}$ Ofwel, omdat menselijke voorspellingen steeds secuurder werden verschoof de aandacht naar wat men wilde communiceren met woordkeuze. Dit leidde vervolgens tot een onbevredigende conclusie, namelijk dat het voor een mens onmogelijk is om de realiteit te vatten in een aantal woorden. Dus stelde Lyotard, zullen universiteiten als gevolg van deze onbevredigende uitkomst terugvallen in het meetbare tegen de achtergrond van het onopgeloste taalprobleem. Hij deed hiermee een opzienbarende voorspelling over de huidige cultuur binnen de academische gemeenschap, die net zoals zijn 
hypothese terug kruipt in wat meetbaar is.

Het beoefenen van academische disciplines was grotendeels weggelegd voor een kleine gegoede bovenlaag. Eenmaal binnen deze elite bestond er een strenge inachtneming van de academische mores omdat onderzoek enorm duur was. Eveneens waren de meeste wetenschappers breder en algemener ontwikkeld als gevolg van een klassiek curriculum. Ook werden hun bevindingen minder snel betwijfeld door de rest van de maatschappij, de sector was immers een niche. Academisch onderzoek was voor veel mensen zo ver van hun bed, dat vooral groepen met een machtoogmerk zich kritisch uitspraken tegen de wetenschap. Kerken en vooral reactionaire groepen waren berucht voor het verbranden van boeken en het censureren van onderzoeken die hun doctrine of ideologie ondermijnden. Met de komst van de secularisatie verdween de kritiek op de wetenschap niet. Het uiten van buitenproportionele scepsis verschoof van grotere organisaties naar de persoonlijke opvattingen en ervaringen van mensen.

In de eenentwintigste eeuw is het vergaren van bronnen en de toegang tot bronnen zwaar gedemocratiseerd. Helaas blijft het aantal mensen met de vaardigheid om deze bronnen correct te analyseren soms achter de gedemocratiseerde toegang tot kennis. Hierdoor ontstaat er een gapend gat van incorrecte analyses, waarin elke Jan, Ria of Thierry dat specifieke, commerciële onderzoek kan gebruiken om hun onethische handelen of vergezochte opvattingen geloofwaardigheid bij te zetten. Dit is problematisch omdat de individuen zich in zekere zin altijd kunnen beroepen op hun recht tot meerdere interpretaties, juist omdat de academici van de postmodernistische traditie hebben aangetoond dat er niet één waarheid is. De vaak linkse postmodernisten hadden waarschijnlijk nooit gedacht dat hun roep voor democratische interpretatie een stimulans zou geven aan de gangbaarheid van termen als 'boreaal'.

Waar taal eerst een normatieve betekenis had zien historici vandaag de dag dat hun onderzoek een meer persoonlijke betekenis omvat. Tegenwoordig nemen peer-reviewers mee wat rationaliteit betekent voor de schrijver specifiek. Naar mijn mening een juiste benadering, omdat dit ook ruimte biedt voor creativiteit en diversiteit tussen onderzoekers. Door zijn of haar kaders er bij te nemen, is het voor een lezer gemakkelijker om te begrijpen waar iemand vandaan komt. Het is aan de onderzoeker in kwestie om een zo oprecht mogelijk verhaal te schrijven, wetende dat dit verhaal altijd gelimiteerd zal zijn door een onoverbrugbare laag subjectiviteit. De contemporaine historicus houdt zich bezig met deze subjectiviteit, verwerkt 
dit transparant in zijn of haar publicaties en spreekt collega's aan bij een gebrek hieraan.

Op een maatschappelijk niveau is het van belang dat de historicus zijn woordkeuze aanpast aan de overweldigende hoeveelheid informatie. Tijdens het schrijven van een onderzoek moet er aandacht zijn voor hoe de publicatie wordt ontvangen. Voorafgaand aan het digitale tijdperk was er veel meer vertrouwen in de expertise van de wetenschapper, mede omdat pseudowetenschap minder naar de voorgrond kon komen. Onderzoek was als niche activiteit van de bovenklasse erg duur en exclusief, nu kan iedereen met een laptop en een Starbucks-beker de holocaust onderzoeken (of problematischer, interpreteren). Dat klimaatwetenschap bijvoorbeeld betwist kan worden, is het resultaat van een te groot podium voor een ongeïnformeerd publiek. Alternatieve feiten zijn te vinden in onbeperkte mate. Om te voorkomen dat de historicus ondergesneeuwd wordt door Breitbard of Infowars is het ook van belang dat zijn of haar woordkeuze een toelichting krijgt. Middels 'de best mogelijke verklaring' bijvoorbeeld, leggen wij aan het publiek uit dat er een zorgvuldig onderzoek is uitgevoerd. Dit onderzoek is desalniettemin uitgevoerd door mensen die bewust zijn van hun persoonlijke kaders en onderzoekscapaciteiten. Terugkeer naar een elitaire en gesloten beoefening van academisch onderzoek is onmogelijk en onwenselijk. Woordkeuze kan echter een rol spelen bij de geloofwaardigheid van een onderzoeker en kan de sleutel zijn in het onderscheid.

Ten slotte dient de historicus zijn of haar specialisering te benadrukken. Historici van verschillende disciplines kunnen nog weleens nadruk leggen op andere aspecten van het verleden. Een cultuurhistoricus zal zich eerder richten op de achterliggende traditie van belastinginning terwijl een economisch historicus statistisch weergeeft waarom de belastingen zijn toegenomen. Deze distantie lijkt logisch maar thema-gerichte onderzoekers hebben zelf vaak voorkeuren voor een reconstructie. Deze reconstructies vertellen andere verhalen met een andere toon, ondanks dat er geschreven wordt over dezelfde gebeurtenis. Zodra niet alleen het bronmateriaal anders is maar ook het type gebruikte bron, kan men niet spreken over één geschiedenis van de belasting. De leek die een onderzoek over Engelse belastingen in de dertiende eeuw leest zal meer de globale implicaties rondom belasting meekrijgen en zichzelf vanzelfsprekend inleven bij het lijden van de betalende partij, bij uitstek de horigen. Dit terwijl de sociaaleconomische historicus uitermate precieze, technische termen gebruikt en louter spreekt in woorden zoals 'toename' of 'afname'. 
De lezer zal vaak een conclusie trekken op basis van voor- en willekeur omdat de historicus er van uit gaat dat de distantie tussen onderzoeken van verschillende specialisten een gegeven is. Edelen betaalden ook belasting, belasting maakte publieke projecten mogelijk en een afname of een toename is weinig omvattend zonder een gedegen ethische onderlegging. Het gaat ver om de leek conclusies te laten vormen over onderzoeksresultaten die niets zeggen over de moraliteit van belastingen. Tenzij u wenst dat de lezer hiermee aan de haal gaat is het van groot belang om zo helder mogelijk te communiceren wat het uiteindelijke doel van het onderzoek was, alsmede zijn of haar eigen discipline en vakgebied te benadrukken.

U merkt ook aan mijn toon dat ik een zekere vooringenomenheid bezit. Ik haal het postmodernisme aan en spreek over de kwalijkheid van bepaalde inzichten omtrent klimaatverandering en de holocaust. Ook hieruit valt een zekere interesse te destilleren en het is belangrijk dat u ook hier aandachtig bent bij het lezen van dit stuk. Met de intrede van Foucaults analyse hebben historici moeten nadenken over hun kaders. Nog preciezer, op welke manier deze kaders schadelijk kunnen zijn voor het reconstrueren van het verleden. Lyotard benadrukte de implicaties van het digitale tijdperk en de manier waarop deze de wetenschap richting een semantisch speelveld heeft begeven. De democratisering van kennis heeft gezorgd voor een meer persoonlijke beoordeling van het werk van historici, vaak op basis van onterechte of buitenproportionele scepsis. Dit kan naar mijn mening gepareerd worden door als historicus meer te letten op transparantie en taalgebruik. Een beter onderzoek uitvoeren zal een leek niet meer overtuigen. Duidelijker uitleggen hoe het is uitgevoerd, waarom het is uitgevoerd en wie het heeft uitgevoerd misschien wel.

\section{Noten}

1. Philip Barker, Michel Foucault: An introduction, (Edinburgh: Edinburgh University Press, 1998): 30-31.

2. Barker, 43 .

3. Barker, 49-50.

4. Jean-François Lyotard, The Postmodern Condition: A Report on Knowledge, (Manchester; Verenigd Koninkrijk: Manchester University Press, 1979). 